\title{
MINORITY IDENTITIES AND THE CONSTRUCTION OF RIGHTS IN POST-SOVIET SETTINGS ${ }^{1}$
}

\author{
Kristin Kuutma, Elo-Hanna Seljamaa, Ergo-Hart Västrik
}

\begin{abstract}
This article looks at the emergent policies and legal constraints shaping identity constructions within and for minority groups in Estonia and in northwest Russia, in order to investigate the processes of 'minority-building' and emergent state policies through cultural entanglements. The case studies discussed comprise legal regulations and measures for the promotion of minority identities in Estonia with special focus on Estonian Russians, the country's biggest and most diverse minority; the Seto, their cultural heritage construction and the question of intangible rights in the border zone between Estonia and Russia; and the Votians and the process of claiming a minority status in Russia in the context of recent socio-economic developments. These three studies enable us to explore the reverberations of Soviet nationality policy as well as new hybrid policies, strategies and self-conceptions emerging in a particular region. This collaborative article proposes a supplement to the study of identity constructions in the post-Soviet setting of minority-buildings that are inherently interdependent and complementary for understanding the possible developments in this sphere.
\end{abstract}

Keywords: identity construction, minority-building, state policies, cultural heritage, post-Soviet

Social theorist Zygmunt Bauman has stated that identity is "a hopelessly ambiguous idea and a double-edged sword" (Bauman 2004: 76). It is a concept that is hotly contested, being at the same time a socially necessary convention. Identity is inherently related to yearning for (communal) belonging that emerges under the condition of insecurity - it is a struggle against dissolution and fragmentation that "comes to life only in the tumult of battle" (ibid.: 77). The oppositions that battle under the current condition of "liquid modernity"2 concern the belonging by primordial assignment and belonging by choice. In the following analysis of the identity battles in two contemporary post-Soviet states we do not consider the former belonging as a given one, but rather detect the enabling moments for the latter in the framework of collective interaction with the state. 
The current article proposes to look at the emergent policies and legal constraints shaping identity constructions within and for minority groups in Estonia and in northwest Russia. Our aim is to analyse these issues from particular perspectives that illuminate the processes of 'minority-building' in that geo-political region, while observing these developments through the lens of 'culture' when analysing state policies. We discuss here three case studies: legal regulations and measures for the promotion of minority identities in Estonia with special focus on Estonian Russians, the country's biggest and most diverse minority; the Seto, their cultural heritage construction and the question of intangible rights in the border zone between Estonia and Russia; the Votians and the process of claiming a minority status in Russia in the context of recent socio-economic developments. Thus, the following analysis does not intend to cover all details or varieties of minority construction in Russia, but focuses more on Estonia and the related border-region or the 'imagined' outreach defined by language and cultural affinities. Moreover, case studies selected for this article enable us to explore the reverberations of Soviet nationality policy as well as new hybrid policies, strategies and self-conceptions emerging in diverse, yet interconnected post-Soviet settings. The current collaborative article pulls together research results of three different projects ${ }^{3}$, but we hope that our juxtaposing analysis sheds additional light on emerging dovetailing issues that allow a broadening of the insight into the construction of minority identities in this particular region, when taking into account the geopolitical and historical circumstance at hand. Even if these three cases may appear incommensurable in proportion and political significance, they nevertheless all add important nuances to the comprehensive picture of the post-Soviet setting of minority-building that is inherently interdependent and complementary for understanding the possible developments in this sphere.

It could be argued that the prevailing understanding of nationality/ethnicity in the region under scrutiny in our contribution has its historical roots in the specifics of Soviet nationalities policy as well as the preceding imperial "institutionalisations of difference" (Werth 2009), but it is also supported by the more general ideology of nationalism that imagines the 'naturalness' of nations (cf. Handler 1994). The Soviet approach distanced itself from earlier imperial confessional categorisations of the population and focused on ethnicity or descent, equating it with nationality, culture and language, and the idea of an 'ethnic homeland'. This conception of bounded ethnic/national groups has inevitably shaped both the majority and minority understandings of the Self and the Other in Estonia as well as in Russia. While the state creates material and political incentives for minorities to become organised around their language and cultural heritage, this very means of claim-making simultaneously 


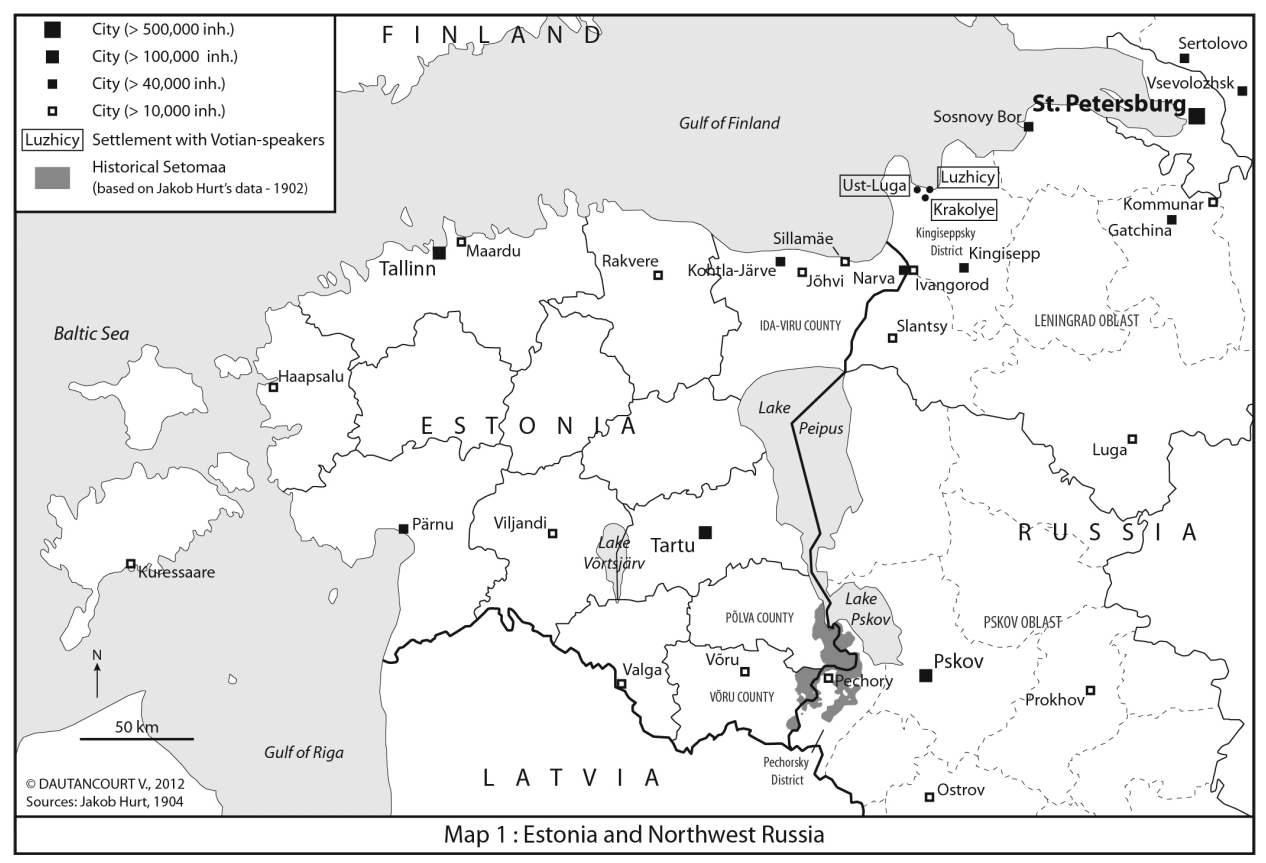

restricts minorities' abilities to participate in political processes and, furthermore, secures the position of the state-bearing ethnic/national groups. Minority policies and legislations in Estonia today are, for the most part, targeted at Russians and seek to define their place within the Estonian society, which simultaneously complicates the position of other (emergent) minorities like the Seto. The position of the latter finds particular significance in the question of national borders with Russia, an issue that continues to be unresolved two decades into independence, yet both the Seto and the Votians remain relatively marginal from the perspective of the Estonian and Russian state, respectively.

According to Giorgio Agamben, the nation state makes "nativity or birth [...] the foundation of its own sovereignty" (cf. Agamben 2000: 20). But while demanding cohesiveness, national identity empowers itself by drawing and policing boundaries between 'us' and 'them', whereas other, 'smaller' identities need to seek endorsement from state-authorised institutions that confirm the superiority of 'national identity' (Bauman 2004: 22). The current study looks at the emergent interactions with the state in the context of identity construction: does the state incite a dialogue, or does it impose its own monologue; does the state insist upon, or create, or preclude a public representational partner.

Therefore the following three analyses investigate the models for communication or contestation of identity employed in relationship with the state: the 
role of institutional representation, the question of cultural autonomy (and its historical baggage), and the creation of spaces where different minority identities can be created, recreated, displayed and negotiated by means of various kinds of performances. The question of language cuts through these case studies, whereas its significance as an identity marker appears to be different for different agents in the region.

\section{SOVIET NATIONALITIES POLICY: PROMOTION AND SUPPRESSION OF DIFFERENCE}

The dissolution of the Soviet Union along ethnic lines and the preceding emergence of nationalist movements in many parts of the Eastern Bloc drew scholars' attention to ways in which the Soviet regime had boosted self-understandings grounded in ethnicity (e.g. Slezkine 1994a; Brubaker 1996) or oscillated continuously between promoting ethnic identities and encouraging assimilation (Gorenburg 2006; see also Simonsen 1999 and Blitstein 2006). Yet both approaches agree that Soviet nationalities policy, stemming from particular Marxist-Leninist-Stalinist ideas about ethnic groups and processes, represented a curious mixture of and tension between celebration and suppression of ethnic particularities. Moreover, it took shape in close and long-term cooperation between scholars and policymakers (e.g. Slezkine 1994b; Hirsch 2005).

The Soviet nationalities policy ${ }^{4}$ came to regard ethnoses as communities of people established historically on a given territory and characterised by relatively steady shared cultural features, language, and psychological traits, as well as by an ethnic self-consciousness expressed in the practices of selfnaming. This meant that membership of an ethnos was based on descent while borders between ethnoses were imagined to be real and essentially territorial, containing entities that had an objective reality to them. The term nationality (natsional'nost) resembled that of ethnos for both words signified ethnic affiliation and were used to distinguish ethnic communities from each other. From 1932 onward, each individual was assigned an official nationality, recorded in one's internal passport - the so-called "fifth line" - and became part of the person's legal status, shaping both education and career prospects (Simonsen 1999). ${ }^{5}$ A nation, in turn, was regarded as the main type of ethnic community at the stage of capitalism and socialism, but would arguably cease to exist, as socialism would be transformed into communism. According to Stalin's influential definition, a nation was "a historically evolved, stable community based on a common language, territory, economic life and psychological make-up 
manifested in a community of culture" (cited and discussed in Slezkine 1994a: 415-416).

In the 1920s-30s in particular, Soviet ethnographers collaborated with the country's leaders to identify ethnic groups, decide over their territory as well as status within the ethno-federalist system (worthy of a union republic, autonomous republic or a smaller autonomous district) (Hirsch 2005). During this period of indigenisation (korenizatsiia), the communist party used ethnoterritorial recognition, promotion of native officials and the boosting of native literary languages in an effort to facilitate the modernisation of groups deemed to be backward, which in turn was expected to speed up the revolutionary process. However, the indigenisation policy did not concern all ethnic groups of the former Russian Empire. For example, several minority groups (including the Votians) were regarded too marginal for independent agency in this process, being united with bigger, linguistically close groups. Thus this policy entailed favouring some groups at the expense of suppressing or even not recognising others. Yet, these nation-building policies came to a rather abrupt end in the mid-1930s, when Soviet policies shifted towards creating the homogeneity needed for the functioning and development of a modern society (cf. Blitstein 2006: 290). In practice, this meant increasing the role of the Russian language and that of Russians: pushed into the background during the indigenisation campaign, they were now trusted with the omnipresent and transparent status of representatives of modernity. However, though this modernisation arguably went beyond nationality and ethnic particularities, in many cases it was perceived as Russificiation by the objects of these policies. Gorenburg argues that despite shifts over time in one direction or another, affirmative action like native language education went hand in hand with the promotion of Russian as the language of interethnic communication, which contributed to processes of linguistic assimilation and reidentification as well as ethnic reidentification (Gorenburg 2006: 276-277).

\section{DISCOURSES OF INCLUSIVITY AND EXCLUSIVITY IN POST- SOVIET ESTONIA}

In the Estonian SSR, this oscillation between particularisation and homogenisation contributed to the division of the permanent population and society into Estonians and Russian-speakers. While the system of ethno-federalism nurtured Estonians' sense of Estonia as a country of and for the Estonian nationality, this sense of ownership was undermined by a constant in- and outflow of immigrants from other parts of the Soviet Union. ${ }^{6}$ As a result, Estonia's ethnic 
composition and population underwent drastic changes during the Soviet era: while the 1934 census recorded 51 national groups, the last Soviet census in 1989 registered 121 nationalities; the population was up from 1.12 million to 1.56 million (Hallik 2010: 9). Individuals of various nationalities from other parts of the Soviet Union, who settled in Estonia, were usually integrated into the Russian-language societal culture that had come to existence after the war and paralleled cultural, educational and other institutions operated in Estonian, the language of the titular nationality. There was also an ethno-linguistic division of labour, linked to settlement patterns with Estonians prevailing in the agricultural countryside and Russians and Russian-speakers in the northeastern industrial region.

Hence, the permanent population of the Estonian SSR was multinational, but first and foremost Estonian and Russian or Russian-speaking. This same division lingers on twenty years into independence, attesting to the formative impact of Soviet nationalities policy on imagining and managing ethnicities, nations, majorities and minorities in post-Soviet settings. While under Soviet conditions the fate of the Estonian language became equated with that of the Estonian nation, language has since been further intertwined with statehood to the point that according to the preamble of the Estonian constitution, the very raison d'être of the Republic of Estonia is to grant the preservation of the Estonian nation, language and culture through ages (Constitution of the Republic of Estonia). Who counts as a member of this nation is, however, highly contestable. Estonia's population is currently 1.34 million, of which self-identifying Estonians comprise $69 \%(924,600)$, Russians $25 \%(335,000)$, Ukrainians $2 \%(26,800)$, and Belarusians $1 \%(13,400)$. The remaining $2 \%$ of the population $(26,800)$ includes representatives of at least 117 nationalities since the Estonian state presents itself as a home to over 120 nationalities. ${ }^{7}$

This discourse of multiplicity and inclusivity stands in stark contrast with the daily division of society into Estonians and Russian-speakers, a term that is immensely multi-layered and hence difficult to pin down. The rationale behind it is to acknowledge that not everybody who speaks Russian is ethnically Russian, i.e., of Russian descent. At the same time it serves as a synonym for 'non-Estonian', lumping as it does all Estonia's ethno-linguistic Others together. By doing this, the term 'Russian-speaker' recreates and maintains the language-based division of society and, moreover, downplays and conceals the fact that the vast majority of Russian-speakers would in fact define themselves as ethnic Russians. It also suggests that language is an ethnic trait, not about communication but being: because 'Estonian' is an ethnonym, Russian-speakers remain Russian-speakers even after they become citizens of Estonia and even if they are fluent in Estonian. As such, 'Russian-speaker' comes across as an 
imagined Other of the Estonian majority, which is not to say that it lacks empirical content or validity altogether. Rather, as will be argued below, it is a category for othering that can be operationalised and hence summons what it claims to be describing.

Moreover, representing Estonia as a home to over 120 nationalities tends to be confined to festive occasions showcasing Estonian statehood and democratic traditions. ${ }^{8}$ When Estonia reclaimed independence in 1991 as the legal successor of the pre-war Republic of Estonia, it restricted its demos to rightful citizens or individuals who had been or were descended from pre-war citizens of Estonia. ${ }^{9}$ While this jus sanguinis approach to citizenship itself was not tied to ethnicity, it had the effect of excluding the majority of Soviet-era settlers and their descendants, who towards the end of the Soviet era constituted one third of Estonia's population of 1.56 million (Sakkeus 1999: 322). Another significant outcome of legal restorationism for minorities was that it enabled in 1993 a return to the 1925 Law on Cultural Autonomy for National Minorities, which was initiated by Baltic-German parliamentarians and was, indeed, innovative for its time. Though the majority politicians and representatives of minorities alike use the existence of the Law on Cultural Autonomy for National Minorities (Rahvusvähemuste kultuurautonoomia seadus) to emphasise Estonia's democratic traditions and make claims of various kinds, it is not fully functional and, given that it has been around for nearly two decades already, is presumably not intended to be 'in working order'. However, like any facade, it does important work. In connection with Estonian Russians, it is significant that the law provides a legal basis for distinguishing between historical or indigenous 'national minorities' (Russians, Jews, Germans, Swedes) and minority individuals who lack "longstanding, firm and lasting ties with Estonia". Individual Russians living in Estonia could fall into either category, Old Believers representing the one extreme and Soviet-era immigrants with undetermined citizenship the other. While different representatives of Russians in Estonia have twice tried to apply for a right to start the process required to establish the status of cultural autonomy, the Ministry of Culture rejected both of them after consulting selected Russian cultural organisations, claiming that the applicants were not representatives of Estonian Russians as a community. This illustrates how the Law on Cultural Autonomy allows the state to strategically bestow representative authority on selected minority organisations in order to deny greater autonomy to the minority as a whole. 


\section{ESTONIAN INTEGRATION POLICY: IDENTITIES PRESERVED AND MADE}

The national integration policy formulated in the late 1990s and implemented since $2000^{10}$ seeks to tie these different fears, aspirations and expectations together through an approach, which similarly to Soviet nationalities policy combines homogenisation or unification (citizenship, Estonian language) with the celebration of ethnic/national differences. First, Estonian integration policy seeks to support the unification of the public sphere on the basis of the Estonian language and citizenship as well as the maintenance of ethnic differences in the private sphere by providing minorities with means to develop and preserve their ethnic cultures. Second, it claims that only Estonians as the majority have the right to a societal culture operated in their native language and that the relationship of the Estonian culture to the state is qualitatively different from that of minority cultures. Group rights of the minorities are restricted to cultural rights, meaning that "opportunities have been created for ethnic minorities and for new immigrants living in Estonia to learn their mother tongue and culture, practice their culture, and preserve and present their ethno-linguistic identity". ${ }^{11}$

It could therefore be argued that the Estonian integration policy operates with different, even contradictory notions of identity: belonging by virtue of descent and choice. The state identity is regarded in social constructivist terms as a project of becoming for it needs to be strengthened, developed, reinforced and in some cases (Mätlik 2008: 11) it is admitted to be something that still needs to emerge and take shape. Ethnic belonging, on the other hand, is taken for granted and treated as something that is always there, preceding the individual, who is born into a national category. According to this view, the population consists of a specific number of ethnic groups, all of which correspond to more or less the same criteria: language, culture, ethnic homeland. This dual approach evokes parallels with Soviet nationalities policy and brings to mind nationalist notions of nations "as natural objects or things in the real world" (Handler 1994: 29). This shows, furthermore, how minority and majority identities are constituted mutually, as the entitativity and abundance of minority groups in Estonia supports claims for the distinctiveness of Estonian national identity and vice versa.

Rather than merely providing minorities with the means to preserve and develop their language and culture, the post-Soviet Estonian state has invested in minority-building. There are currently over 300 cultural societies and other organisations of different ethnic nationalities, including over 60 organisations that claim to represent Russians in Estonia. While their stated goal is usually to preserve, develop and represent a particular national culture in Estonia and 
thereby contribute to integration in Estonia, most of them could be described as dance or music ensembles, choirs or amateur theatres targeted at particular age groups. ${ }^{12}$ Most of them also receive funding from the Ministry of Culture, for which they have to apply on a regular basis. This strategy for institutionalising minority identities is based on the idea of pre-existing subjects and reinforces notions that equate ethnicity with inherited nationality, language and selected cultural traits. The strategy also encourages and relies on individual ethnic entrepreneurship, which raises important questions regarding one's authority to speak on behalf of a whole nationality as well as regarding the power of the state to pick its partners.

Perhaps most importantly, this system determines the rules and criteria that individuals self-identifying with particular descent have to comply with in order to qualify for and receive official recognition as an ethnic minority. By setting the standards for acceptable minority identities, the state simultaneously assigns a particular role to non-Estonians within Estonian society and restricts their activities to the private sphere. In this way the state frames minorities as collective bearers of inherited national cultures and discourages them from becoming organised around socio-political issues or making claims that would contradict the state's nationalising policies. While this privatisation of ethnicity has no implications on most ethnic groups in Estonia, it restricts the claimmaking opportunities of Russians and Russian-speakers. A striking example of this is the reform of Russian-language secondary education in Estonia, as a result of which $60 \%$ of subjects are to be taught in Estonian by the autumn of 2012. According to a nationalist reading of the bilingual school system, sending non-Russian children to a Russian school amounts to Russification and is thus condemnable, while schools with Estonian as the language of instruction are neutral to the extent that Estonian is the state language.

Estonia's strategic choice to balance the boosting of similarity and difference confirms the point made by Craig Calhoun that instead of treating essentialism and constructionism as opposites, it is "important to see a field for possible strategies for confronting issues of identity" (Calhoun 1994: 17). Moreover, the renewed popularity of the Soviet Victory Day among Russians and Russianspeakers in Tallinn suggests that identification processes are in fundamental ways beyond the control of state-funded programmes and policies. The visibility of May 9th celebrations in the capital started to grow around 2005, which is also when Russia restored its tradition of grand Victory Day military parades on the Red Square in Moscow. While it would be easy to frame the commemoration of Victory Day in post-Soviet Estonia as an expression of loyalty to Russia or nostalgia for the Soviet era, such an interpretation would comply with the nationalist definition of culture that denies the minorities' public participation 
in society as well as coevalness with their Estonian fellow countrywomen and -men. Many inhabitants of Tallinn, who protested against the relocation of the Bronze Soldier monument in spring 2007, protested against the way it was done rather than the decision to move it to a cemetery. This meant that they also protested against the way they were being treated and communicated within their own home country or country of permanent residency.

The moving of the monument to the cemetery of defence forces has opened up a new space where different minority identities in Estonia, Russian-speaker being one of them, can be created, recreated, displayed and negotiated by means of various kinds of performances. Victory Day in particular brings people together at regular intervals to carry out specific practices that have acquired a recognisable and repeatable form over the last years: community emerges, as Dorothy Noyes has put it, from re-enactment, formalisation and consensus (Noyes 1995). There are, no doubt, actors who use Victory Day celebrations to pursue their own political agenda or that of particular political forces in Russia, but these, too, are strategies for confronting identities and their outcomes emergent rather than predetermined.

\section{CONSTRUCTIONS OF SETO IDENTITY AND RIGHTS}

The current study addresses inherently the issue of constructing rights, rights to identity and rights to culture. If in the case of Estonian Russians the state is decisively involved in the process of 'minority-building' (and privatisation of ethnicity) in the framework of a state-driven integration agenda, then the Seto case presents the process of 'minority-building' driven from within, in the format of a public claim for separate/distinct ethnic identity.

At the same time Seto identity politics and the performance of Seto identity actively recognises the significance of the cultural aspect; it is instrumental in their claim for and performance of difference inside the nation state. Cultural identities are produced in a wider discourse of political rights; they manifest a reaction to the political and administrative authority of homogenisation of the nation state. The community's self-representational ideals reflect how people situate and establish themselves in a wider global context, but also the state politics of heritage management. Cultural heritage is a seminal element in signifying difference, its construction and identification is always an act of politics and power, depending on who defines it, and who is in control of conceptualising its stewardship. On the other hand, when regarding the perspective of the state, the implementation of the framework of 'culture' stands out as a prominent preference. 'Culture' is endorsed at the state level for its capacity to 
provide a relief in potential conflict situations; as pointed out by Anna Tsing, it serves the state as an alternative to politics that might complicate the state's authority (cf. Tsing 1993).

The Seto are a small ethnic group of roughly 8-10,000 inhabiting the border zone between southeast Estonia and northwest Russia. Their identity construction emanates from a combination of versatile liminalities, rising from the geographical placement. Today most of the Seto live in Estonia, but the Seto region (Setomaa) is divided between Võru and Põlva counties of southeast Estonia, and the Pechorsky administrative district of northwest Russia. The social and political changes of the 20th century have caused the Seto to move outside their historic region, mainly to cities. A complex interplay of continuous social and political marginalisation on the one hand, and an active idolisation of Seto cultural heritage on the other, define their cultural expression. Those powerful external constraints have produced significant internal response, revealed in the sentient traditionalisation of Seto culture, which empowers particular groups, rhetoric and interests. In Estonia, the Seto have functioned for about a century as the imaginary 'cultural reservoir' of pre-industrial practices and lifestyles, nurtured by the interaction of ethnographic research with heritage production and cultural policy making, with discursive impact on local communities and their cultural expression.

The construction of Seto ethnic identity reverberates the different phases of the Estonian nation state ambivalently through the past century. Based on the scholarly research of linguistic ties, which was also prominent in the late-nineteenth-century Estonian nation-building process, the Seto claim individual Finno-Ugric descent. ${ }^{13}$ Though today they carry a two-dimensional Seto-Estonian identity (cf. Jääts 1998), their 'Setoness' becomes manifest in their usage of the Seto language ${ }^{14}$, their skills in and understanding of the traditional singing style, their maintenance of communal and family traditions, and the veneration of their passed ancestors. Their cultural practices defined by rural lifestyle stem from communal land farming and the Russian Orthodox Church, which contrasts to the farming methods and predominant Protestant Lutheranism in Estonia, at least from the historical perspective. Their present social status considered, the Seto seem to be integrated into the general prevailing Estonian framework, although their territorial and sociopolitical integration with Estonia (and foreseeable enculturation) took effect only in the $1920 \mathrm{~s}^{15}$ The linguistic and cultural historians of the time found fascination with their distinct cultural expression, whereas the Seto remained at the same time stigmatised by their primitive communal farming and alien Orthodox religious practices, recreational customs or prevalent illiteracy in the eyes of the general public. On the other hand, they inhabited the border region 
with Russia, which deemed the integration of this region to the overall framework of the Republic of Estonia as a task of acute political interest. At the time, the question of cultural autonomy did not arise at all, due to the marginal and stigmatised status of the Seto, as well as their total lack of individual agency in the national framework.

Following World War II, political circumstances changed for the Seto along with the rest of Estonia under the Soviet regime, although their marginalisation, assimilation, and celebration found its extremes at different times due to the circumstances of ongoing modernisation and urbanisation (Hagu 1999; Jääts 1998). The political situation of the dismantling of the Soviet Union and of reclaiming independent Estonia eventually severed the Seto region between separate states by the gradually established political border of the 1990s. ${ }^{16}$ Since part of the Seto district has been officially annexed to Russia - which leaves Petseri ${ }^{17}$, the historical centre of the region, inaccessible behind the border - the painful constraints of the mainstream realpolitik made the Seto increasingly conscious of their regional, historical and cultural identity (cf. Jääts 1998; V. Sarv 1997; Raun 1991). The Seto are Estonian citizens, but have declared through their local representative body of the Seto Congress that they are "first and foremost Seto" (VI Seto Kongress). In the context of the Seto movement ${ }^{18}$ and in its struggle for outside socio-political recognition and cultural survival, all distinct elements of Seto heritage have gained vital importance.

\section{POLITICAL CONSTRAINTS OF MINORITY BUILDING}

In escalated efforts to emend and reinstate the political border between Estonia and Russia, the Seto remained demoted as political objects in state politics. However, through that aggravating process they arose as political subjects, observant of their individual regional and cultural agendas (cf. Hagu 1995; Õ. Sarv 1997). In 1993, the Seto convened a representative body, the Third Seto Congress ${ }^{19}$, to voice their rights and interests, and address the disruption of, and communication with, that part of Setomaa that remained on the other side of the concretely materialising border. The congress resolution document stipulated that "[a] treaty should be concluded between the Republic of Estonia and the Russian Federation on the issue of protection of economic, cultural, religious and political rights of the indigenous population [of Setomaa]" (Seto Kongress 1994: 121). Separate resolutions were also adopted concerning the rights of the Seto language, culture, and education (ibid.: 124-125). This representative organisation of the local and diaspora Seto communities holds the highest advisory power on Seto matters, and elects an executive body, the Board 
of Elders. Although they have no independent political position in the nation state framework, the government has recognised their representative capacity at certain moments. For example, when a group of Seto activists with political merit $^{20}$ sought a legislative act to attain cultural autonomy, the Ministry of Culture required a relevant decision from the Seto Congress. This body has not reached a consensus yet on the matter, but has adopted resolutions on founding the Seto National Park. Actually, for the political activists of the Seto community, the decision on how or to what extent they should or could declare their distinct identity in the public sphere and political arena has been neither easy nor unanimous; this is an issue of constant contestation, negotiation and debate.

In 2000, the census of the Republic of Estonia denied the Seto the right that they had campaigned for - to register separately. This eventually found a resolution at the Sixth Seto Congress, in 2002, which proclaimed the Seto a separate people, 'a nation' (see Õ. Sarv 2008). This declaration stated that the Seto are an indigenous people who have lived in their lands since "time immemorial", without ever being aggressive towards their neighbours, nor do they seek trouble in the future: "The Seto expect all other nations to acknowledge the Seto right to live as a nation in their indigenous homeland and to speak their own language." (VI Seto Kongress) Despite the prevailing denouncement of extremist claims, the most painful problem continues to be the severance of their historical region by the establishment of the political border in 1994, which meant cutting off families on both sides, denial of access to land ownership, visa restrictions for visiting the capital of Petseri, or the adjacent Seto graveyards. The recent Seto Congresses have considered it "treacherous" to accept the political demarcation line set by the Russian Federation (e.g. Vananurm 2002: 139), and declare it the basis for the violation of human rights. ${ }^{21}$ The Ninth Seto Congress, in 2008, made an official appeal to the Parliament of the Republic of Estonia to denunciate the current Border Treaty, which violates the property rights and human rights of the Seto: "The citizens of the Republic of Estonia are denied free access to and movement in their indigenous home." (Seto Kongress)

Russia, in turn, has taken a different course of action. Even though the number of the resident population of Seto origin in the present borders of the Russian Federation is remarkably small (a few hundred), the Seto were officially registered as a numerically small indigenous people in Russia in 2010. Though understandably marginal, the Seto ethnicity functions as a player (or rather pawn) to serve the cause of a more sophisticated international politics.

The border problem indicates how national development, economic and political interests overrule local concerns and human rights. The Estonian state does not register the Seto as a separate ethnic group, ${ }^{22}$ though their indigenous 
cultural interests are recognised to a certain extent. Because of the political complications in the $1990 \mathrm{~s}$, and due to active Seto lobbying ${ }^{23}$, the government established a separate commission to address "the Seto problems" in 1996 and launched a programme of Setomaa Regional Development, mainly engaged with economic issues. There is a similar state-funded programme for culture, the Setumaa Cultural Programme, initiated in 2003 as "a national programme aiming to support the cultural activity of Setu people, who have a unique language and cultural heritage and live in four parishes of southeast Estonia" (State programmes). It is basically a funding project, operated from the Ministry of Culture with the help of a board that comprises, however, only four representatives from Setomaa out of its ten members. The issue of cultural autonomy remains on the agenda, though debated. This is tacitly related to territorial unification and cooperation, officially in the confines of the nation state, but with an aspiration to transform the violation of Seto rights for cultural selfhood. At the moment, the Seto region of four Seto municipalities is divided between two administrative units in southeast Estonia that are governed by non-Seto centres and neighbours. In order to further, and manage, Seto matters, a local cooperative NGO, the Union of Setomaa Rural Municipalities (Setomaa Valdade Liit) was founded in 2005. For the activists of this grassroots organisation, the questions of cultural autonomy and the setting up of a national park remain a top priority (cf. Timmo 2006; Hõrn \& Alumäe 2004). Even though this organisation performs the important task of facilitating collaboration for the Seto across administrative borders ${ }^{24}$ and furthering local culture, they often remain neglected in areas where state interests are concerned. For example, the Seto advocate native-language classes and protest against planned administrative reform, which, for economic reasons, plans to ignore the Seto requests to form a unified Seto administrative region.

\section{THE SIGNIFICANCE OF CULTURAL RIGHTS}

In the last decade, the Seto have developed significant cultural and political activism, seeking an outlet at both national and international levels with the intention of providing means and support for the advancement of autonomous recognition: firstly, particularly via the Finno-Ugrian affiliation and the FinnoUgrian World Congress, and, secondly, the UNESCO programmes on state-level policies regarding intangible cultural heritage. In the context of international recognition, Finno-Ugrian affiliation appears to be of particular significance. The Seto participate in a regional grassroots organisation, the Finno-Ugrian World Congress, where they have a separate delegation of representatives alongside 
the Estonian delegation. The World Congress is the representative body of Finno-Ugric peoples, established in 1992, and the Seto seek full membership in their Consultative Committee ${ }^{25}$. Finno-Ugrian affiliation is important and instrumental for the Seto in their perception of cultural selfhood and management of cultural politics. This is inherently connected with the constant configuration of identity for a community that needs to define its fleeting selfhood, related to the cultural framework and the problematising of cultural rights in the multidimensional identification process. This is signified by the frequently voiced question "who are we" (kiä' mi' olõ?), to position the Seto identity in Estonian, European, and Finno-Ugric cultural space (see M. Sarv 2009). In addition to this, the Seto have employed UNESCO programmes, particularly on state-level policies, which relate to intangible cultural heritage. Their first initiative was to gain acknowledgement as a national park or culture-nature reserve under UNESCO protection (see Rahvuspark). Later they launched a more successful project in the framework of intangible cultural heritage to secure legal commitment and safeguarding from the Estonian state. With the determined objective of gaining national and international acknowledgement, the Seto community leaders took action to define and promote their intangible cultural heritage in correspondence within the UNESCO guidelines (cf. Kuutma 2009). Cultural heritage functions for the Seto as an operational asset in negotiating affirmative action at the state level, while activities that identify viable elements of cultural practice for the survival of Seto heritage have found celebratory recognition in the UNESCO framework. This selective public acknowledgement of cultural practices affects local Seto politicians, especially when they argue with the state - and particularly at the regional (non-Seto) administrative level - that UNESCO recognition renders them authority to demand a unified Seto district.

The Seto in this study represent an identity construction defined by language, lifestyle and religious practices, while the constraints of the border zone have developed their regional, historical and cultural identity into demands for political ethnic recognition. For the Seto as a community, cultural rights appear to take precedence in the public contestation of human rights. Although the border region constraints are painful, the public dispute over political rights has given priority to cultural issues. They have endorsed cultural politics to achieve resolution in the ongoing marginalisation, while their historical experience does not favour demands for political rights. 


\section{VOTIANS: A PROBLEMATIC CONSTRUCTION OF ETHNIC IDENTITY}

Another case of 'minority building' driven from within is revealed when analysing recent processes related to institutionalisation of cultural rights and (re)construction of ethnic identity among the Votians, a Finno-Ugric minority group ${ }^{26}$ in northwest Russia, Leningrad Oblast, close to the Estonian-Russian border. The present-day socio-political situation in Russia provides certain prescribed forms for cultural activism under state control. The Votian case illuminates the endeavours of a marginalised minority group to achieve recognition under heavy pressure of economic development in their indigenous territory.

Although today one of the marginalised minority groups of northwest Russia, researchers have regarded the Votians as the oldest known indigenous group of the region. As a distinct tribe the Votians appeared in the arena of written history in the 11 th century $\mathrm{AD}$, apparently giving their name to one of the administrative units of the former Novgorod Republic (see Kirkinen 1991), which has allowed researchers to see the Votians as more important players in medieval regional politics than indicated by their current situation. Their language, beliefs and customs have been studied since the scholarly community of early ethnographers, linguists and geographers discovered this minority group at the end of the 18th century. The Votians have particularly attracted the attention of Finnish and Estonian researchers, who searched for aspects of past culture they presumed to have disappeared in their home countries but were still observable among kindred peoples. Therefore Votian folk culture, like that of the Seto, has for researchers served as a window to peep into the ancient past of the 'more developed' peoples (cf. Anttonen 2005: 172-175). There is also another side to this coin: systematic fieldtrips of Estonian linguists and folklorists to Votian villages since World War II have ultimately supported Votian self-identification as a separate ethnic group.

Similarly to the Setos, rural lifestyles and the Russian Orthodox Church defined the folk culture of the Votians. Their sources of livelihood were based on communal land farming and cattle breeding, which in coastal areas was combined with collective fishing, ship-building and navigation (cf. Talve 1981). It was St. Petersburg, the capital of the Russian Empire, which provided the Votians with new possibilities of livelihood related to marine trade and transportation. The vicinity of the metropolis, however, eased assimilation, which went hand in hand with modernisation. Marginalisation was accelerated during the Soviet era when the Votians were not listed as subjects of the indigenisation policy. The cataclysms of World War II brought mass deportations to Finland and to various regions of the Soviet Union (cf. Markus \& Rozhanskiy 2011: 15-16). During 
the post-war period inhabitants of the region had to give up their traditional means of livelihood because of restrictions in the border zone. The territory of former Votian villages was gradually depopulated and only the developments related to the construction of the Ust-Luga multifunctional seaport since the early 1990s have brought new investments and jobs to the region.

Numeric data about the Votians date back to the middle of the 19th century demography statistics, which counted 5,184 Votians in 37 villages in St. Petersburg Province (Oranienbaum and Yamburg uyezds), where they lived together with Ingrians ${ }^{27}$, Finns and Russians (von Köppen 1867). The "ethnographic groups" described were perceived as bounded entities that can be divided into indigenous groups, formed in a certain period, and migrant groups who reached the region later (cf. Handler 1994: 29). Nevertheless, P. von Köppen's listings reveal that most of these villages had mixed populations, whereas later data about inter-ethnic marriages indicate that borders between the Votians and the others were not hermetic. There are descriptions from the early 20 th century according to which inhabitants of those villages rarely identified themselves as Votians, but often labelled themselves willingly as Ingrians (relying on their non-Russian language) or Russians (according to the common Orthodox creed), when asked (cf. Tsvetkov 2009).

The ethnic history of the Votians can be described as the story of marginalisation, where socio-economic circumstances have supported assimilation with majority groups. In the context of Soviet indigenisation policies of the $1920 \mathrm{~s}-30 \mathrm{~s}$, the Votians requirement for a literary language and an autonomous territory of their own was considered marginal. For a short period of time Votian children were partly taught in Ingrian, which evidently raised the status of the Ingrian language in the local multilingual environment (cf. Markus \& Rozhanskiy 2011: 14). From 1926 the Votes were excluded from the Soviet censuses as an autonomous ethnicity, while their domestic passports inscribed them either as "Russian" or "Ingrian" (izhor).

All later statistics and researchers' estimations of the numbers of Votians have indicated a continuous decrease in population (e.g. Ernits 1996). This has not meant so much physical extermination or deportations but the process of assimilation, because those who earlier identified themselves as Votian have voluntarily ceased to do so by taking over other identifications that are more prestigious or convenient. Their stigmatisation after World War II led even to conscious concealment and repudiation of their ethnic origin. Parents ceased to teach their native language to children, which meant that the use of Votian gradually diminished, and in the early 1990s the community of Votian speakers consisted of a few dozen elderly people in three villages (cf. Heinsoo 1992). 


\section{ETHNIC REVIVAL AND THE INSTITUTIONALISATION OF IDENTITY}

Despite these processes of ethnic and linguistic re-identification, in the late 1990s a Votian ethnic revival emerged in Luzhicy (Luutsa), one of the last villages where Votian was spoken as the vernacular language. The revival manifested itself in various cultural activities including, for example, the foundation of a grassroots Votian Museum, revitalisation of local village feasts as the foremost manifestation of ethnic revival and performance of identity, presentation of the Votian national flag, coat of arms and anthem, launch of Internet homepages dedicated to 'Votian affairs', and the publication of a small-scale local newspaper (cf. Västrik \& Võsu 2010; Heinsoo \& Kuusk 2011). The museum and the village feast have mobilised a group of cultural activists from nearby urban centres as well as from the village. These people, altogether 15-20 in number, come from diverse ethnic and educational backgrounds. Some of them have Votian roots, but only few of them have the (passive) knowledge of Votian, which means that the common language of communication within the group is Russian. Notwithstanding this, the vernacular language has an important symbolic meaning in this revival. For example, a children's folklore group from the Krakolye Basic School has performed songs and poems in Votian in the programme of the Luzhicy village feast, and classes in native language and cultural history were organised at the local school for some years.

A small number of ethnic activists have tried to rehabilitate this voiceless, repressed and unacknowledged minority group by taking the initiative and proposing various cultural activities. They have contested the official representation of history in regional museums and promoted their own alternative interpretations of Votian cultural heritage, opposed to the non-recognition policy of the state. In a decade the activists have considerably advanced the Votian identity of their fellow villagers, changed the general attitude towards their (parents') legacy and achieved the (re)introduction of the Votian ethnonym. Votians also reappeared as an autonomous ethnicity in the pan-Russian census in 2002 , when actually no more than 73 people declared themselves as belonging to this ethnic group (Perepis 2002). ${ }^{28}$

Since 2005 the activities of the revival movement have been channelled through the Society of Votian Culture NGO. One of the society's most recent efforts was the process of claiming status among 'numerically small indigenous peoples' (korennye malochislennye narody) for the Votians. This status was introduced by Federal Law in 2000, in order to support minorities with a population of less than 50,000 in the Russian North, Siberia and Far East who "live in the traditional territory of their ancestors and maintain their traditional 
lifestyle, management and trade" (see Federal'nyi zakon 2000). The Votians were inserted into this list in October 2008, after a proposal articulated by the authorities of Leningrad oblast.

The upsurge of Votian ethnic identity in the mid-1990s can be seen as a reaction to the rapid changes in the economic infrastructure of the region. Ethnic revival coincided with endeavours to construct a multipurpose merchant seaport of Ust-Luga next to Luzhicy village. Construction work started in 1995 and since then seven colossal terminals have been opened, providing jobs for more than 2,000 people. According to the official construction plan publicised in November 2007, the intention was to replace the small villages of Krakolye and Luzhicy (altogether ca. 250 permanent inhabitants) with a modern town of 35,000 future port workers and their families. This project created severe protest among the local inhabitants and Russian academic institutions, who underlined the prospective negative effect on the self-esteem of the Votians, their community and heritage (MariUver 2008). For example, in the meeting with the local administration on November 12, 2007, representatives of the Society of Votian Culture pointed out that the construction of the new town would endanger the "last compact territory of the Votians with their heritage sites and natural environment" (Kuznecova 2008: 3). At the meeting with the representatives of the seaport, the society proposed the idea of creating "a historical-ethnographic reserve (an ecological park)", which would "allow the persistence of the Votians henceforward" (ibid.).

After this meeting the representatives of the port affirmed that houses in Luzhicy and Krakolye villages would not be removed and, even more, the architecture of the future town would introduce "elements of Ingrian and Votian culture that would give to the new town an original touch" (AllNW 2008). The spokesperson of the seaport confirmed the plan to construct a museum of local history in the future port workers' town. In the same press release, however, the director of the Ust-Luga Company questioned the very existence of the Votians as a distinct ethnic group, announcing that they do not have official status in the list of indigenous peoples of Russia, and claiming: "Thus, de jure, such a minority does not exist." (ibid.)

The Votian activists in turn sought help on the issue from academics and managed by March 2008 to secure official certifications from three top institutions in Moscow and St. Petersburg (the Institute of Linguistics of the Russian Academy of Sciences, the Russian Museum of Ethnography, and the Peter the Great Museum of Anthropology and Ethnography; see Prilozhenie 2008). These letters, signed by the highest administrative authorities, proved the existence of the Votians as a distinct ethnic group and testified to the research on them by Russian scholars. The Society of Votian Culture forwarded the confirmation 
letters to the provincial government from where these were addressed to the Government of the Russian Federation. As a result, on October 13, 2008, the President of Russia granted the Votians the official status of a 'small indigenous people' by decree (Postanovleniye 2008).

Thus we may contend that in the case of the Votians, the process of ethnic and cultural identification has been related to the recognition of threats from outside. This development reflects citizen activism in redefining heritage, which should be seen in the wider context of ethnic revival in the Russian Federation (see Shabaev \& Sharapov 2011). The recreation of ethnic identity has been practiced and employed by grass-roots institutions and highlights the performative and interpretive nature of the process of identity creation. The community of researchers has also played an important role in the process of conscious minority-building by enabling cultural activists to use scholarly interpretation to further their agenda. However, the indigenous minority having official status does not guarantee stability and the avoidance of further marginalisation as support is confined mainly to the rhetoric of government authorities.

\section{CONCLUSION}

The study of the presented three cases focused on the emergent practices and performances of minority identities, while acknowledging the scholarly critique problematising the analytical value of the identity concept (cf. Brubaker \& Cooper 2000). The production and management of ethnic identities are negotiated in the discursive context of interrelations and oppositions, and they reflect power plays in the region and beyond, e.g. the Finno-Ugric movement or relevant UNESCO cultural programmes. These may provide minorities with an international framework that lends an opportunity to find a representational forum that transcends local limitations. Identity concerns are born "out of the crisis of belonging" (Bauman 2004: 22), often in response to societal changes and legal constraints that make minorities conscious of their position as well as political and cultural agendas. At the same time, universal rights and policy documents acquire meaning by being applied in local variation, where they may find agency in different aspects. Thus communities should be investigated as interrelated particularities - different circumstances make them perceive and employ rights differently. By turning an investigative eye to the claimed universality of rights, we should admit and recognise an enabling resolve in pluralist approaches (cf. Messer 1997). It seems important not only to elucidate negative experience and the violation of rights but to define and investigate moments of empowerment, real instances of achieving subjective agency in 
identity politics. We have traced some enabling moments of "confronting issues of identity" (Calhoun 1994) where the deemed objects of national/ethnic politics may manage to become subjects with agency. By exploring notions, management and application of national and ethnic identities, our analyses have shown the majority and minorities to be mutually constitutive.

The post-Soviet Estonian state invokes ethnic identities by creating incentives for minorities to become organised around their cultural heritage, while at the same time constraining ethnic difference to the private sphere and marginalisation. Estonian Russians as the largest minority nationality in Estonia occupy a betwixt and between position, which both increases and reduces the opportunities of other minorities: partially in an effort to prevent non-Russian minorities from self-identifying as Russian-speakers or Russians, the state has established means for supporting a plethora of different ethno-national identities, but the same fear also keeps it from encouraging minorities' active participation in the shaping of Estonian public sphere, which is imagined as the privilege of the titular nationality. These tensions are captured in the struggles of the Seto over native-language education and border disputes as well as in the term 'Russian-speaker', which both reinforces and undermines the link of ethnicity to language and by extension also to ethnonyms, territory and descent - the core elements of the Soviet concept of nationality/ethnicity play a significant role in the self-understanding of all three groups discussed in this article. Language and territorial issues cut through the three studies here on a different level, but point out significant aspects of identity-building. For the Seto, the claim for a distinct language is a relatively new political asset that is played out inside the community but remains nearly totally ignored at the state level where language issues are contextualised largely by the Estonian-Russian controversies. The Votian circumstance testifies to the role of language mainly on the symbolic plane as a signifier of historical indigeneity and sedentary residence, even if the modern population has shifted its language use. All three case studies indicate that the state's recognition of minorities is selective, subject to changes over time and, moreover, that the state can impact the identity processes of a group by favouring particular activists and groups over others. This concerns another feature in minority construction that we have observed, namely representative organisations of minority groups. The state can strategically favour an established and representative body in negotiations of specific matters, while at the same time creating a situation in which it rivals other organisations for resources as well as attention.

The case of the Seto and the Votians in particular illustrates how minorities look for external, inter- and transnational support to renegotiate their status and opportunities at home. For example, the Finno-Ugrian movement and different 
initiatives by UNESCO provide minorities with opportunities for advancing local agendas. Estonian Russians, most of them Soviet-era settlers and their descendants, lack (at least seemingly) neutral external supporters of this kind, especially since Russia's policies for co-nationals "in the near abroad" can be easily interpreted from the perspective of the Estonian state as an attempt to undermine Estonia's efforts to integrate local Russians.

For the Seto and the Votians, the question of cultural rights is predominant, while political rights through self-determination have shaped their identity construction and appear strongly intertwined in the past decades. Some of these transcend the state; some seek interaction with the state with purposeful agendas. Cultural heritage functions as an operational asset in negotiating for affirmative action at the state level. One may conclude that the previous agendas of cultural researchers to preserve repertoires or retain cultural practices have now been replaced by grassroots politics that enable activists to voice concerns for human rights via targeted actions in cultural rights. External constraints enable and produce internal responses that empower particular groups, rhetoric and interests and particular internal actors.

\section{NOTES}

1 Research for this article was partly funded by the Estonian Science Foundation grants No. 7795, 9190 and 9271, and the European Union through its European Regional Development Fund (Centre of Excellence in Cultural Theory, CECT).

2 According to Bauman it is the continuation of modernity that is defined by fluidity of social frameworks and institutions; these are times of increasing mobility, characterised by feelings of uncertainty (Bauman 2000).

3 For analytic purposes and for the sake of argument, this study addresses the level of politics played out. Individual research projects have involved the collection of various data, including interviews, participant observation, surveys of policy documents, media coverage, archival material, etc., which have been carried out between 2006 and 2011.

4 The following discussion of ethnoses, nationality and nations draws on Bromley 1974; Bromley 1980; Dragadze 1980; Kozlov 1974 unless otherwise stated. For a discussion of Soviet (ethnographers') concepts of ethnicity and nationality from a Western perspective, see, e.g., Shanin 1986; Verdery 1988; Comaroff 1991.

5 A practice discontinued in the Russian Federation in 1997 (Arel 2003).

${ }^{6}$ Between 1946 and 1991 this flow involved nearly 2.9 million people in Estonia, which means that only every fifth migrant stayed for a shorter or longer period of time (Sakkeus 1999: 320). 
7 See the web portal Etnoweb initiated by the Estonian Ministry of Culture (Etnoweb web portal).

8 Cf. Eesti 90, website of the 90th anniversary of the Republic of Estonia.

9 The Citizenship Act came into force in 1992, just before the first parliamentary elections in the newly independent country, securing a fully Estonian Riigikogu (Parliament). Though many people have become naturalised citizens since, over $7 \%$ of Estonia's permanent residents have not determined their citizenship and over $8 \%$ are citizens of Russia. The rate of naturalisation slowed down in the mid-2000s and after April 2007 in particular.

10 The state programme "Integration in Estonian society in 2000-2007" was followed by a strategic plan "Estonian Integration Strategy 2008-2013".

${ }^{11}$ Eesti lõimumiskava 2008-2013, p. 20.

${ }^{12}$ See the Etnoweb web portal for details.

13 This is officially stated by the Seto Congress, concurring with the claim by scholars of Seto origin (Seto Kongress 1994: 115). Finno-Ugrian affiliation is based on linguistic ties, historically defined by language research. This language family joins Estonians, Finns, Hungarians, dispersed groups in northern Russia (including the Votians) and Siberia, as well as the Sámi.

${ }^{14}$ Similarly to Estonian, the Seto language falls into the Finnic group of the Finno-Ugric language family. Academic linguists have declared Seto to be a dialect of Estonian (being mutually understandable particularly for those in neighbouring southern Estonia), although modern Seto activists contest this vehemently.

${ }^{15}$ In the tsarist Russian Empire they formed a linguistically distinct rural population who followed the Orthodox creed in the margins of Pskov province, outside of the confines of the Baltic provinces. For details on Seto history, see, e.g., Raun 1991; Hagu 1999.

16 The debated issue was the 1920 Tartu Peace Treaty, which had determined the interwar period borders of Estonia, covering part of the present Pechorsky district.

${ }^{17}$ Pechory in Russian, a trading and monastery town.

${ }^{18}$ A socio-cultural movement to gain recognition and amplify Seto identity with complex cultural and territorial interests, cf. Jääts 1998.

19 The first two Seto congresses were held in the 1920s, initiated by Estonian cultural activists for educational purposes (cf. Hõrn 2008).

${ }^{20}$ Their leader has sat in the Estonian Parliament (see Poliitika and Järvelilli Reinu...).

${ }^{21}$ Estonia gave up its territorial claims against Russia as a prerequisite for joining the European Union in 2004.

${ }^{22}$ The reason may be both the intention to retain the claim of identified 'historical minorities', or the incapacity of the community to reach a consensus. 
${ }^{23}$ Noteworthily supported by Estonian politicians campaigning for the restoration of pre-WWII Estonian borders.

${ }^{24}$ And expanding their activities into the neighbouring municipalities and Seto-linked cultural institutions in Russia.

${ }^{25}$ The coordinating body that acts in conformity with the rules of international law and the principles of the United Nations Organization. See The Consultative Committee.

${ }^{26}$ The Votian language belongs to the Finnic group of Finno-Ugric languages (cf. footnotes 11 and 12). Thus we are dealing here with close linguistic proximity to Estonian, in contrast to its difference from Russian.

${ }^{27}$ Another larger Finnic minority group in the region.

${ }^{28}$ This number was questioned by the expert linguists because the census results indicated the number of Votian speakers to be ten times bigger (774), which would apparently be a mistake (see Heinsoo \& Kuusk 2011: 176; Markus \& Rozhanskiy 2011: 16). According to the pan-Russian census of 2010, the number of Votians was 64 and the number of Votian-speakers 68 (Perepis 2010).

\section{REFERENCES}

Agamben, Giorgio 2000. Means without Ends: Notes on Politics. University of Minnesota Press.

AllNW 2008 = "Kompaniia Ust'-Luga" ozabotilas' kulturoi malykh narodov. ["Ust'-Luga Company" is concerned about the culture of minority groups.] In: AllNW.ru. Oficialnyi portal Severo-Zapada Rossii i Leningradskoi oblasti. [Official portal of North-West Russia and Leningrad Oblast.] http://lenobl.allnw.ru/news/56637, last accessed on 29 January 2012.

Anttonen, Pertti J. 2005. Tradition through Modernity: Postmodernism and the NationState in Folklore Scholarship. Studia Fennica. Folkloristica 15. Helsinki: Finnish Literature Society.

Arel, Dominique 2003. Fixing Ethnicity in Identity Documents: The Rise and Fall of Passport Nationality in Russia. In: Canadian Review of Studies in Nationalism XXX, pp. 125-136.

Bauman, Zygmunt 2000. Liquid Modernity. Cambridge: Polity Press.

Bauman, Zygmunt 2004. Identity: Conversations with Benedetto Vecchi. Cambridge: Polity Press.

Blitstein, Peter A. 2006. Cultural Diversity and the Interwar Conjuncture: Soviet Nationality Policy in Its Comparative Context. In: Slavic Review, Vol. 65, No. 2, pp. 273-293.

Bromley, Yulian 1974. The Term Ethnos and its Definition. In: Yu. Bromely (ed.) Soviet Ethnology and Anthropology Today. The Hague: Mouton, pp. 55-72.

Bromley, Yulian 1980. The object and the subject-matter of ethnography. In: E. Gellner (ed.) Soviet and Western Anthropology. London: Duckworth, pp. 151-160. 
Brubaker, Rogers 1996. Nationalism reframed: nationhood and the national question in the New Europe. Cambridge \& New York: Cambridge University Press.

Brubaker, Rogers \& Cooper, Frederick 2000. Beyond "Identity". In: Theory and Society 29, pp. 1-47, doi: 10.1023/A:1007068714468.

Calhoun, Craig J. 1994. Social Theory and the Politics of Identity. In: C. Calhoun (ed.) Social Theory and the Politics of Identity. Oxford, UK \& Cambridge, MA: Blackwell, pp. 9-36.

Comaroff, John 1991. Humanity, Ethnicity, Nationality: Conceptual and Comparative Perspectives on the U.S.S.R. In: Theory and Society, Vol. 20, No. 5, Special Issue on Ethnic Conflict in the Soviet Union, pp. 661-687, doi: 10.1007/BF00232664.

Constitution of the Republic of Estonia. http://www.eesti.ee/eng/riik/pohiseadus/, last accessed on 27 January 2012.

Dragadze, Tamara 1980. The Place of 'Ethnos' Theory in Soviet Anthropology. In: E. Gellner (ed.) Soviet and Western Anthropology. London: Duckworth, pp. 161-170.

Eesti 90 (website of the 90th Anniversary of the Republic of Estonia). http://www.eesti90. ee/index.php?id=10449\&month=10\&year=2008, last accessed on 20 January 2012.

Eesti lõimumiskava 2008-2013. [Estonian integration plan for the years 2008-2013.] http://www.kul.ee/webeditor/files/integratsioon/Loimumiskava_2008_2013.pdf, last accessed on 28 January 2012.

Ernits, Enn 1996. Vatjalaisten assimiloitumisen historiaa. [Assimilation history of Votians.] In: Kyösti Julku et al. (eds.) Historia Fenno-Ugrica I: 1. Congressus Primus Historiae Fenno-Ugricae. Oulu: Societas Historiae Fenno-Ugricae, pp. 193-206.

Etnoweb web portal. http://www.etnoweb.ee/, last accessed on 28 January 2012.

Federal'nyi zakon 2000 = Federal'nyi zakon ot 20.07.2000 n 104-fz (red. ot 02.02.2006) ob obshchikh printsipakh organizatsii obshchin korennykh malochislennykh narodov Severa, Sibiri i Dal'nego Vostoka Rossiiskoi Federatsii (priniat GD FS RF 06.07.2000). [Federal Law No. 104-fz of 20.07.2000 (redaction of 02.02.2006) about general organization principles of communities of numerically small indigenous peoples of the Northern Territories, Siberia and Far-East of the Russian Federation.] http://www.lawmix.ru/zkrf/655, last accessed on 29 January 2012.

Gorenburg, Dmitry 2006. Rebounding Identities: The Politics of Identity in Russia and Ukraine. In: D. Arel \& B.A. Ruble (eds.) Soviet Nationality Policy and Assimilation. Baltimore: The John Hopkins University Press, pp. 273-303.

Hagu, Paul 1995. Setukaisten identiteetin ongelmat. [Identity problems of Setos.] In: T. Saarinen \& S. Suhonen (eds.) Koltat, karjalaiset ja setukaiset. Pienet kansat maailmojen rajoilla. [Koltas, Karelians and Setos. Small peoples on the edges of the world.] Kuopio: Snellman-instituutti, pp. 169-181.

Hagu, Paul 1999. Setukaiset - raja-alueen ortodoksivähemmistö. [Setos - Orthodox minority of the border region.] In: T. Laitila \& T. Saarinen (eds.) Uskonto ja identiteetti: Suomalais-ugrilaisten kokemuksia ja vaiheita Venäjällä ja Neuvostoliitossa. [Religion and identity: Experiences and developments of Finno-Ugrians in Russia and Soviet Union.] Helsinki: Suomalaisen Kirjallisuuden Seura, pp. 82-95.

Hallik, Klara 2010. Koos pole lihtne aga eraldi ei saa. [Together it is not easy but it is not possible apart.] Tallinn: Rahvusvaheliste ja Sotsiaaluuringute Instituut. 
Handler, Richard K. 1994. Is 'Identity' a Useful Cross-Cultural Concept? In: J. R. Gillis (ed.) Commemorations: The Politics of National Identity. Princeton: Princeton University Press, pp. 27-40.

Heinsoo, Heinike 1992. Vatjalaisista ja vatjalaisuudesta. [About Votians and Votianness.] In: Sananjalka 34, pp. 164-170.

Heinsoo, Heinike \& Kuusk, Margit 2011. Neo-renessaince and revitalization of Votic - who cares? In: Journal of Estonian and Finno-Ugric Linguistics, Vol. 2, No. 1, pp. 171-184.

Hirsch, Francine 2005. Empire of nations: Ethnographic knowledge \& the making of the Soviet Union. Ithaca, New York: Cornell University Press.

Hõrn, Aare 2008. Seto Kongressi' läbi aoluu Setomaa piirkonna eloh. [Seto congresses through history in the life of Setomaa region.] In: Setomaa 21 (175), pp. 6-7.

Hõrn, Aare \& Alumäe, Helen 2004. Vana tiidmine ja loodusõ usk hoitvaq Setomaa loodust. [Ancient knowledge and nature religion protect nature in Setomaa.] In: Eesti Loodus. Erinumber 2004 (55), pp. 56-59.

Järvelilli Reinu ilmutõtu kirotuisi ja kõnõsid. [Published articles and speeches by Rein Järvelill.] In: Seto Arvutileht. [Seto e-journal.] http://www.seto.ee/Jarvelilli-Rein. html, last accessed on 29 January 2012.

Jääts, Indrek 1998. Setude etniline identiteet. [The ethnic identity of the Setus.] Studia Ethnologica Tartuensia 1. Tartu: Tartu Ülikooli etnoloogia õppetool.

Kirkinen, Heikki 1991. Inkerin keskiaika ja uuden ajan alku vuoteen 1617. [Middle ages and the beginning of the modern era up to 1617 in Ingria.] In: Pekka Nevalainen \& Hannes Sihvo (eds.) Inkeri: historia, kansa, kulttuuri. [Ingria: History, people, culture.] Helsinki: Suomalaisen Kirjallisuuden Seura, pp. 35-66.

Köppen, Peter von 1867. Erklärender Text zu der ethnographischen Karte des St. Petersburger Gouvernements. St.-Petersburg: Kaiserliche Akademie der Wissenschaften.

Kozlov, Viktor 1974. On the Concept of Ethnic Community. In: Yu. Bromely (ed.) Soviet Ethnology and Anthropology Today. The Hague: Mouton, pp. 73-87.

Kuutma, Kristin 2009. Who Owns Our Songs: Authority of Heritage and Resources for Restitution. In: Ethnologia Europaea 39 (2), pp. 26-40.

Kuznecova, Ekaterina 2008. Vod' - problemy i vozmozhnosti kul'turnogo vozrozhdeniia. [Votians - problems and possibilities of cultural revival.] In: Vodskaia gazeta Maaväci [Votian newspaper Maaväci], No. 9, pp. 1-3.

MariUver 2008 = Rossiiskiie vlasti unichtozhaiut posledniie vodskiie derevni. [Russian officials are destroying last Votian villages.] http://mariuver.info/rus/news/ soc/2008/01/20.html, last accessed on 29 January 2012.

Markus, Elena \& Rozhanskiy, Fedor 2011. Sovremennyi vodskii jazyk. Teksty i grammaticheskii ocherk. Tom I. Vodskie teksty. [Contemporary Votian language. Texts and grammatical outline. Vol. 1. Votian texts.] Sankt-Peterburg: Izdatelstvo Sanktpeterburgskogo instituta istorii RAN "Nestor-Istoria".

Mätlik, Tanel 2008. Estonian Integration Strategy 2008-2013. In: Tallinn Conference on Conceptualizing Integration. October 18-19, 2007. Tallinn: Integration Foundation, pp. 8-12.

Messer, Ellen 1997. Pluralist Approaches to Human Rights. In: Journal of Anthropological Research 53, No. 3, pp. 293-315.

Noyes, Dorothy 1995. Group. In: Journal of American Folklore 108, pp. 449-478. 
Perepis 2002 = National composition of population. In: 2002 All-Russia Population Census. http://www.perepis2002.ru/index.html?id=87, last accessed on 29 January 2012 .

Perepis 2010 = Nacionalnyi sostav naselenia Rossiiskoi Federacii. [National composition of the population of the Russian Federation.] In: Informacionnye materialy ob okonchitel'nykh itogakh Vserossiiskoi perepisi naselenia 2010 goda. [Informational materials about the final results of all-Russia population census of the year 2010.] http://www.gks.ru/free_doc/new_site/perepis2010/perepis_itogi1612.htm, last accessed on 29 January 2012.

Poliitika. Erinevä poliitilisõ tekstiq. [Politics. Various political texts.] http://www.seto. ee/Poliitika.html, last accessed on 29 January 2012.

Postanovlenie 2008 = Postanovlenie Pravitel'stva RF ot 13.10.2008 N 760 "O vnesenii izmenenii v Edinyi perechen' korennykh malochislennykh narodov Rossiiskoi Federacii". [Decree of the government of the Russian Federation from 13.10.2008 No. 760 "About inserting changes to the list of numerically small indigenous peoples of the Russian Federation".] In: Pravovoi portal PRAVO.ru. [Law portal PRAVO.ru.] http://www.inpravo.ru/baza1/art8d/nm-1ibve5.htm, last accessed on 5 July 2012.

Prilozhenie 2008 = Prilozhenie 1 k Vodskoi gazete "Maaväci" No. 9. [Supplement No. 1 to the Votian newspaper Maaväci.] In: Vodskaia gazeta Maaväci [Votian newspaper Maaväci], No. 9.

Rahvuspark. [National Park.] In: Seto Arvutileht. [Seto e-journal.] http://www.seto.ee/ Rahvuspark.html, last accessed on 30 January 2012.

Rahvusvähemuste kultuurautonoomia seadus. [Law on cultural autonomy for national minorities.] https://www.riigiteataja.ee/akt/182796, last accessed on 27 January 2012.

Raun, Toivo U. 1991. The Petseri Region of the Republic of Estonia. In: Jahrbücher für Geschichte Osteuropas 39. Stuttgart: Franz Steiner Verlag, pp. 514-532.

Sakkeus, Luule 1999. Migratsioon. [Migration.] In: J. Viikberg (ed.) Eesti rahvaste raamat. Rahvusvähemused, -rühmadja-killud. [Book of peoples of Estonia. National minorities, ethnic groups and subgroups.] Tallinn: Eesti Entsüklopeediakirjastus, pp. 310-325.

Sarv, Maarja 2009. Kiä' mi olõ? Seto identiteet Eesti, Euroopa ja Soome-ugri kultuuriruumis. [Who are we? Seto identity in Estonian, European and Finno-Ugric cultural room.] In: Setomaa 13 (191), p. 6.

Sarv, Õie 1997. Ei saa me läbi Setota ja Venemaa meelest ei lähe ... [We can’t do without Setomaa and we do not forget Russia .... In: Lee 4: Ümin. Tartu: Eesti Rahva Muuseumi Sõprade Selts, pp. 96-99.

Sarv, Õie 2008. Läämi’ vasta Seto Kongressilõ. [Seto congress will be held soon.] In: Setomaa 15-16 (169-170), p. 11.

Sarv, Vaike 1997. Üheksa nimega hõim. [Tribe with nine names.] In: Setomaa 2 (11), pp. 1-2.

Seto Kongress. [Seto Congress.] http://www.setomaa.ee/index.php?id=6e2713a6efee97 bacb63e52c54f0ada0, last accessed on 30 August 2009.

Seto Kongress 1994 = Kolmas Seto Kongress: 9.10.1993 Värskas. [Third Seto Congress: 9.10.1993 in Värska.] Tartu: Tartu Ülikooli Kirjastus. 
Shabaev, Yuri \& Sharapov, Valery 2011. The Izhma Komi and the Pomor: Two Models of Cultural Transformation. In: Journal of Ethnology and Folkloristics, Vol. 5, No. 1, pp.97-122. http://www.jef.ee/index.php/journal/article/viewFile/72/pdf_65, last accessed on 29 January 2012.

Shanin, Teodor 1986. Soviet Theories of Ethnicity: The Case of a Missing Term. In: New Left Review, No. 1/158, pp. 113-122.

Simonsen, Sven Gunnar 1999. Inheriting the Soviet Policy Toolbox: Russia's Dilemma Over Ascriptive Nationality. In: Europe-Asia Studies, Vol. 51, No. 6, pp. 1069 1087, doi:10.1080/09668139998633.

Slezkine, Yuri 1994a. The USSR as a Communal Apartment, or How a Socialist State Promoted Ethnic Particularism. In: Slavic Review, Vol. 53, No. 2, pp. 414-452.

Slezkine, Yuri 1994b. Arctic Mirrors: Russia and the Small Peoples of the North. Ithaca: Cornell University Press.

State programme "Integration in Estonian Society 2000-2007". http://www.kul.ee/ webeditor/files/integratsioon/state_programme111.pdf, last accessed on 28 January 2012 .

State programmes. http://www.kul.ee/index.php?path=0x873, last accessed on $30 \mathrm{Au}-$ gust 2009.

Talve, Ilmar 1981. Vatjalaista kansankulttuuria. [Votian folk culture.] Mémoires de la Société Finno-Ougrienne 179. Helsinki: Suomalais-ugrilainen Seura.

The Consultative Committee. http://www.fennougria.ee/index.php?id=10957, last accessed on 30 January 2012.

Timmo, Margus 2006. Tegelemi ${ }^{q}$ võimaluisiga ${ }^{q}$ [We are dealing with possibilities.] In: Peko Helü. Suvi [Peko's voice. Summer], No. 1, p. 5.

Tsing, Anna Lowenhaupt 1993. In the Realm of the Diamond Queen. Princeton: Princeton University Press.

Tsvetkov, Dmitri 2009. Vadjalased. [Votians.] In: Enn Ernits. Vadja haritlane Dmitri Tsvetkov. [Votian intellectual Dmitri Tsvetkov.] Tartu: Eesti Kirjandusmuuseumi Teaduskirjastus, pp. 197-203.

Vananurm, Ilmar (ed.) 2002. Mu Setomaa. [My Setomaa.] Võru: Setomaa Valdade Liit.

Västrik, Ergo-Hart \& Võsu, Ester 2010. Performing Votianness. Heritage Production, the Votian Museum and Village Feasts. In: Ethnologia Europaea, Vol. 40 (2), pp. 60-76.

Verdery, Katherine 1988. Ethnicity as Culture: Some Soviet-American Contrast. In: Canadian Review of Studies in Nationalism XV, 1-2 (1988), pp. 107-110.

Werth, Paul W. 2009. The Institutionalization of Confessional Difference: 'Foreign Confessions' in Imperial Russia, 1810-1857. In: M. Branch (ed.) Defining Self: Essays On Emergent Identities in Russia Seventeeth to Nineteenth Centuries. Studia Fennica Ethnologica 10. Helsinki: Finnish Literature Society, pp. 152-172.

VI Seto Kongress. [The 6th Seto Congress.] In: Seto Arvutileht. [Seto e-journal.] http:// www.seto.ee/VI-Seto-Kongress.html, last accessed on 29 January 2012. 